\title{
On the Cultivation of Information Literacy of College Students Majoring in English
}

\author{
An Wang ${ }^{1, a}$, Miaomiao $\mathrm{Li}^{2, \mathrm{~b}}$ \\ ${ }^{1}$ Education School, Jiangxi Science \& Technology Normal University, Nanchang, China \\ 2 Jiangxi Science \& Technology Normal University, Nanchang, China \\ a wanganwangmenghua@163.com; ${ }^{\mathrm{b}}$ limiaom8899@163.com
}

Keywords: college students majoring in English, information literacy, cultivating ways

\begin{abstract}
The age of information and the informatization of education bring an important opportunity for college students majoring in English to get rid of “dumb English” and "deaf English”. At the same time, it also makes improving their information literacy become necessary. The paper expounds the definition and the connotation of information literacy, and then analyzes the ways of cultivating students' information literacy.
\end{abstract}

\section{Introduction}

Along with the popularization of the network, the massive information brings great convenience to people's life, but also increases their burden of processing information. The capacity of individual information acquisition and processing directly decides their learning and working performance. In order to enable students to keep pace with the times and handle with information overload, it is very important to cultivate college students' information literacy. As the students in normal colleges and universities, they shoulder the responsibility of improving our country's information technology popularization and application level. With regard to the students majoring in English of normal universities, cultivating and practicing their capabilities of acquiring, processing and using information is to make them become the implementation and disseminator of English information education, which is the important mission of higher education and the prerequisite for lifelong learning.

\section{The connotation of information literacy}

Information consciousness. The information consciousness refers to self consciousness that the person with information literacy ability specifies the information demand and determines the type and degree of the information needed. The specific implementation results show as follows: (1) be able to determine and clarify the information needed; (2) be able to identify potential information sources of different types and formats; (3) be able to estimate the benefit and cost of obtaining the desired information; (4) be able to evaluate the characteristics and expansion of information needed. On the basis of it, CAUL (2001) stressed that the person having information literacy should also aware of the importance of the information, and establish the ideas of respecting knowledge, lifelong learning and innovation in the age of information.

Information knowledge. The information knowledge includes two aspects: (1) basic knowledge of information, mainly refers to the concept, connotation and type of the information; the types and features of the information sources; the theory and basic method of information organization; the basic knowledge of information search and management; the principles and methods of information analysis; the form, type and mode of information exchange. (2) The knowledge of information technology. It mainly includes the role of information technology; the terms of information technology; the basic principles of information technology work and the common equipments of using information technology. 
Information ability. According to the seven standards of information literacy raised by CAUL (2001), information ability mainly includes information retrieval ability, information evaluation ability, information management ability and information generation ability. The specific implementation results of information retrieval ability show as follows: (1) be able to obtain the information needed with the most appropriate method or retrieval system; (2) be able to construct and improve the efficient search strategies, use and select correct command of information retrieval, and make good search strategies; (3) be able to write a summary and record, and manage information and its sources. Information evaluation ability, refers to the ability evaluating the specific implementation results of the information critically, which shows as follows: (1) be able to summarize the central idea from the collected information; (2) be able to make systematical evaluation on the availability, accuracy, authority, timeliness and prejudice; (3) be able to discuss the accuracy of information with others or professionals; (4) be able to screen the collected information and decide whether need other materials; (5) be able to analyze the background, culture and source of obtaining data, and judge the practicability. The specific implementation results of information management ability show as follows: (1) be able to name the information and classify scientifically to make the information resources organization in order; (2) be able to record all the relevant information for future reference; (3) be able to obtain, store and spread information reasonably and lawfully, such as text, data, image, and sound information. Information generation refers to that the person, both the individual and a team, can use the information to achieve a specific objective effectively. The specific implementation results show as follows: (1) be able to create new plans and achievements by using new information and connecting the possessing knowledge; (2) be able to integrate the gist of obtaining information and construct the new concept; (3) be able to judge the accuracy of data sources, the limitation of information gathering tools or search strategy, and the rationality of conclusion by combining the stored knowledge; (4) be able to rethink the success and failure of search strategy; (5) be able to exchange the work or form with others effectively.

Information ethics. It refers to that the person possessing the information literacy ability knows the economic, legal and social problems producing from using the relevant information technology, and abides by the morality and law in obtaining and using the information. The specific implementation results show as follows: (1) be able to understand the ethics, legal and social and economic problems related with information and information technology; (2) be able to comply with the laws, rules and regulations, politeness norms and network behavior specification related with acquiring and using information resources; (3) be able to use the information sources in the exchange work or display form.

\section{Ways of cultivating information literacy of the students majoring in English of normal universities}

Establish the concept of information education. In the age of information, the speed of knowledge updating exceeds any previous period, therefore, it is particularly important to teach students to learn and cultivate them to know how to discover and use the knowledge creatively, so as to acquire the capacity of self learning and self education. In order to adapt to the requirement of modern basic education, the graduates from normal colleges should establish the concept of information education, advocate student-centered exploration or discovery learning, and migrate the idea and ability of information education into English teaching activities. The teachers of normal colleges must set an example and pay attention to making full use of network resources and all kinds of information resources to actively create informatization learning environment for students, cultivate students' learning interest and innovative spirit, and promote the development of students' comprehensive quality.

With English knowledge learning as a carrier, take the information technology as the tool and means to penetrate into English teaching, thus to cultivate students' capacity of solving subject and improve their information literacy. For example, when teaching the lesson "Deserts", the teacher can play the video tape. The towering snow-capped mountains, beautiful waterfalls and dense virgin 
forest will bring students into unlimited reverie and they will praise the amazing and great nature sincerely. Then converse image into the dry land, thirsty children, desolate Gobi, and rare animal bones, which can induce their ideological vibration. Display the discussion topic by using projection to let them discuss the causes of desert, the responsibility of desert expansion human should take on, and measures preventing the problem. After class, let students use the library, campus network or internet to search relevant information around the topic of "man and nature", and then write multimedia research report in groups, which can not only help them to improve English level, but also cultivate their ability of using and innovating information.

Give full play to the role of campus network to build open information environment for cultivating students' ability of acquiring information sensitively and actively in the vast information environment. Campus network is connected with cernet and chinanet, providing all the teachers and students with browsing, E-mail, FRP, BBS, news and other internet service and multimedia application suitable for distance education and video conference. Therefore, the construction and application of campus network provides powerful support for teaching, scientific research, education management and social practice activities. Through campus network, teachers can browse and query online resources easily and quickly at home and abroad to obtain the academic front dynamic information for scientific research, carry out classroom teaching by accessing cyber resources and guide and test students' learning. Some teachers offer "timing electronic office" service to students and students can get teachers' guidance and help in time through e-mail intercom with the time prescribed. Some teachers place their courseware on the internet for peer to download and use, realizing the sharing of resources.

Take education practice as an opportunity to cultivate students' comprehensive ability of using information. Teaching practice is an important link in teachers' training. During the internship, teachers guide students to connect teaching design, teaching multimedia application and software design to cultivate students' comprehensive ability of using information, which is mainly divided into three stages. Firstly, the stage of simulation and practice inside the colleges. According to the teaching content, students choose two classes freely and then design the classroom teaching on the basis of teaching aim, teaching content and students' psychological and thinking characteristics under the guidance of teachers. They should fully consider what kind of media, at what time, in what order, etc, and then make the electronic teaching plan with voice and text, modified by teachers. Secondly, the stage in practice base. When reaching the practice base, students should first grasp the application of multimedia and network technology in English class, learn the experience and methods of teaching design through the multimedia and network, and then further improve their teaching plans on the base of counseling. Thirdly, the stage of practice summary and commendation. Hold the teaching competition and courseware assessment activities to create the teaching atmosphere of using modern technology and means.

\section{Summary}

In summary, discussing the strategies of cultivating information literacy can promote the information literacy of students majoring in English, laying strong foundation for training compound talents and realizing lifelong learning.

\section{References}

[1]Peng Wu. Rearch on information literacy education in Americian universities[D]. Henan University, 2009.

[2]Weiwei Chen, Yi Li. The connotation, levels and cultivation of information literacy[J]. Audio visual education research, 2002(11)

[3]Zhongping Yao, Wenjing Sheng. The status quo of university students' information literacy education[J]. Science Educ, 2010(4). 
[4]Yan Wang. On the effect of university library in the information literacy education[J]. Journal of Xinzhou Normal University, 2010(4).

[5]Li Zhang, et al. The present situation and cultivation of college students' information literacy under the network environment[J]. Agricultural library and information science, 2010(2).

[6]Yongwen Hai. The important class of information literacy education for university students[J]. Agricultural library and information science, 2010(5).

[7]Yulin Gu. On the nformation literacy of college students[J]. Higher education research, 2006(1).

[8]Xiao Hu. Cultivating students' information literacy under the network environment[J]. Chia Adult Education, 2007(1).

[9]Xiaoning Guo. Modern information technology and the cultivation of information literacy of students majoring in English[J]. Foreign Language Teaching, 2002(4). 